\title{
AZ ÖKOSZEMLÉLET KIALAKÍTÁSA ÉS ERŐSÍTÉSE EGY VÁROSI KÖNYVTÁRBAN
}

\section{KÁLLAINÉ VEREB MÁRIA}

\section{Tartalmi összefoglaló}

A kiskunfélegyházi Petöfi Sándor Városi Könyvtár 2007-ben költözött új épületébe. 2008-ban a régi könyvtárépület, a müemléképületben lévő Hattyúház felújítását is befejezték. Az új épületszárnyba kerültek a tényleges könyvtári funkciók (regisztáció, RFID-re épülö kölcsönzés, olvasótermek, gyermekkönyvtári részleg), a régi épületbe az internetes szolgáltatások és a médiatár, továbbá rendezvény-és kiállítóterek kerültek. A felújítás az Európai Unió TIOP pályázata keretében valósult meg. A Madárbarát klub 2011-ben alakult, a madárbarát kertet a könyvtár melletti parkban építették ki. 2015-ben egy nemzetközi kezdeményezéshez kapcsolódva Olvas-lakot (utcai könyvesszekrényt) állítottak fel a közeli parkban, később a buszmegállóban, strandon is. A könyvtár müködtetésében hangsúlyosan figyelnek a humánökológiai szempontokra, az energiatakarékos müködtetésre és az újrahasznositás fontosságára. A szerzö bemutatja a könyvtár tudatosan kialakított új típusú szolgáltatásait.

https://doi.org/10.46280/KOMPKONF.2020.Kallaine

\section{A városi könyvtár bemutatása}

Kiskunfélegyháza Petőfi Sándor és Móra Ferenc városa, de meghatározhatjuk Szántó Piroska és Holló László Kossuth-díjas festőművészek szülővárosaként is. Az Alföldön, Bács-Kiskun megyében található, 30 ezer lakosú város. Intézményei és civil szervezetei révén gazdag a kulturális élete.

A Petőfi Sándor Városi Könyvtár a város központjában található. 2007-ben új könyvtárépület épült, 2008-ban a Hattyúházat, mint műemléképületet teljesen felújították. Kiskunfélegyháza városa 2006-ban nyerte el az utolsó állami címzett támogatást, így 400 millió forintból és a helyi önkormányzat közel 70 milliós támogatásából valósult meg az új könyvtárépület együttes. Ma a könyvtár kettőezer négyzetméteren áll a város és térsége lakossága rendelkezésére.

Az új épületben valósultak meg a valódi könyvtári funkciók: regisztrációs övezet, olvasóterem, gyermekbirodalom. A régi épületben kapott helyet az internet- és médiatár, a helyismereti gyűjtemény, valamint a rendezvény- és kiállítóterem. A kiállítótér kiváló lehetőséget biztosít a könyvtár számára tárlatok rendezésére, mivel nincs a városban ilyen alapterületü, felszereltségü kiállítóterem. 


\subsection{Korszerïsités - eszközfejlesztés}

A korszerűen felszerelt könyvtár számára jó lehetőség adódott, amikor élhetett az európai uniós pályázatokkal. A nyertes TIOP pályázatból megvalósult fejlesztéseknek köszönhetően a városi könyvtár olvasói új szolgáltatásokat vehetnek igénybe. A könyv visszavételezö rendszer segítségével a nyitvatartási időn túl is visszaadhatják a kölcsönzött könyveket.

Az országban - a városi könyvtárak körében - 2009-ben egyedülálló RFID rendszer (olvasóazonosító és állományvédelmi rendszer) kiépítésére került sor. A www.psvk.hu honlapon keresztül az olvasók éjjel-nappal meghosszabbíthatják a náluk lévő dokumentumok kölcsönzési határidejét, előjegyezhetnek dokumentumokat. E-mail, illetve SMS-értesítést kérhetnek kölcsönzéseik határidejének lejáratáról, előjegyzett dokumentum beérkezéséről.

$\mathrm{Az}$ internetes részlegben speciális szoftverekkel és eszközökkel (képernyő-felolvasó szoftver, Braille-kijelző) ellátott számítógép segíti a vakok és gyengén látók könyvtár-, számítógép- és internethasználatát. Az olvasóteremben olvasótévé könnyíti meg a folyóiratok és könyvek olvasását.

A helyismereti gyüjtemény archiválásához, nagyméretű dokumentumok szkenneléséhez nagy teljesítményű szkennert vásároltunk.

\subsection{Szolgáltatásfejlesztés}

A nyertes TÁMOP pályázatban célul tűztük ki, hogy a könyvtár rendszeres látogatói körét megtartsuk, sőt újabb célcsoportokat vonjunk be. A cél megvalósult, a könyvtárnak a város életében elfoglalt szerepét a rendezvények révén emeltük, bővültek a digitális kompetenciák, ezáltal az élethosszig tartó tanulást is támogattuk a lakosság körében. Programjainkkal elösegítettük egyes hátrányos helyzetü csoportok könyvtárhasználatát.

A projektben olvasás- és könyvtárhasználatot népszerüsítő rendezvényeket, foglalkozásokat, vetélkedőket, versenyeket szerveztünk és kampányok lebonyolítását vállaltuk.

Pályázatunkból megvalósult az akadálymentes, többnyelvü, interaktív honlap, ahol a gyermekeknek külön szekciót hoztunk létre. Honlapunkon kulturális és közhasznú, valamint helyismereti információkat tettünk közzé. Feltártuk helyi lapjaink régi számait, ezzel adatbázisunkban kereshetővé vált tartalmuk.

\section{A könyvtár szerepe a helyi társadalomban}

A könyvtárak fontos szerepet töltenek be az adott település életében, így városunkban is. A városi könyvtár a település közszolgáltató intézménye. E feladata közül kiemelhetjük a NAV munkatársának előadásait, amelyet márciusban az őstermelőknek tart. Májusban BácsKiskun megye városaiban, így Kiskunfélegyházán is kitelepülnek a könyvtárakba az adóhivatal munkatársai, ahol segítik a magánszemélyek adóbevallásainak ellenőrzését, leadását, javítását, ügyfélkapu nyitását. A városi könyvtárak jelentős részt vállalnak az Erzsébet és az Otthon Melege programok benyújtásában, majd gondozásában. 
A könyvtárak a település közösségi helyei is. Több klub, kör működik a félegyházi városi könyvtárban, így a Könyvek klubja olvasókör, a Színe-java klub és a Madárbarát klub. A civil szervezetek is szívesen tartják üléseiket, programjaikat a település könyvtárában. Városunkban immár 30 éve a könyvtárban müködik a Móra Ferenc Közmüvelődési Egyesület, mint civil kulturális szervezet, melynek tagjai támogatják könyvtárunk tevékenységét.

A félegyházi városi könyvtár is jelen van a világhálón. Önálló, többnyelvű honlapja, Facebook oldala van. Olvasóink hírlevél formájában kapják meg programjainkról a tájékoztatót, ezzel is kímélve a papírhasználatot.

\section{Régi és új könyvtárépület}

Kiskunfélegyházán az 1960-as, '70-es években nem épült új könyvtár, ahogy Bács-Kiskun megye más városaiban. Az intézmény 1951-ben, majd teljes egészében 1966-ban költözött be a müemléképületbe, a jeles Petőfi emlékhelyre. A hatvanas években, az akkori viszonyok között is törekedtek a teljes helyreállításra. Az átfogó felújítás 2008-ban valósult meg, amikor a fém nyílászárókat fa ablakokra, portálokra cserélték, ablakokat nyitottak és falaztak be, feltárták az épület alatti pincét. Ekkor valósult meg teljes mértékben az eredeti formába történő visszaállítás.

A szűkös körülmények arra ösztönözték az intézmény fenntartóját, hogy éljen az utolsó címzett pályázat lehetőségével, amikor a régi könyvtárépület teljes felújítására és egy hozzá kapcsolódó új könyvtárépület építésére pályázott. A régi épülethez ruhatárral kapcsolódik az új épület. A műemléképület meghatározta az új szárny megépítését, így viszonylag alacsony a belmagasság, érvényesül a természetes megvilágítás, fehérek a falak.

A fenntartó önkormányzat az új könyvtárépület megépítése és a régi épület felújítása során nagy gonddal alakította ki a külső környezetet: parkosított, bokrokat, virágokat telepített, virágosított.

A városi könyvtárban 2011-ben alakult meg a Madárbarát klub, amelynek vezetője összefogva az intézmény munkatársaival - célul tűzte ki, hogy Madárbarát kertet hoz létre a könyvtár melletti parkban. A tradíciókat követve vérszilvafákat ültettünk. Falültetési akciónkkal azt példáztuk, hogy a város építése, szépítése nemcsak költségvetésből oldható meg, hanem jó együttmüködéssel és összefogással is sokat lehet tenni környezetünkért. A Klub kezdeményezésére 2015-ben, a Tavaszi virágünnep keretében Herman Ottó emlékmüvet avatottunk. A kertben madarakat bemutató, népszerüsítő információs táblákat állítottunk fel.

2015-ben csatlakoztunk egy nemzetközi kezdeményezéshez, a Végy egyet - Tégy egyet! akcióhoz. A helyi Kossuth Iskola diákjai igényes Olvas-lakot, könyves szekrénykéket készítettek, amelyet elsőként a könyvtár mögötti parkban helyeztünk el. Később a buszállomáson, a strandon és egyik terünkön is felállítottuk azzal a céllal, hogy az emberek az általuk kiolvasott könyveket ebbe a házikóba elhelyezzék, de a könyvtár is rendszeresen feltölti a lakokat azokból a könyvekből, amelyeket olvasóitól kapott, ill. állományából kivont. 


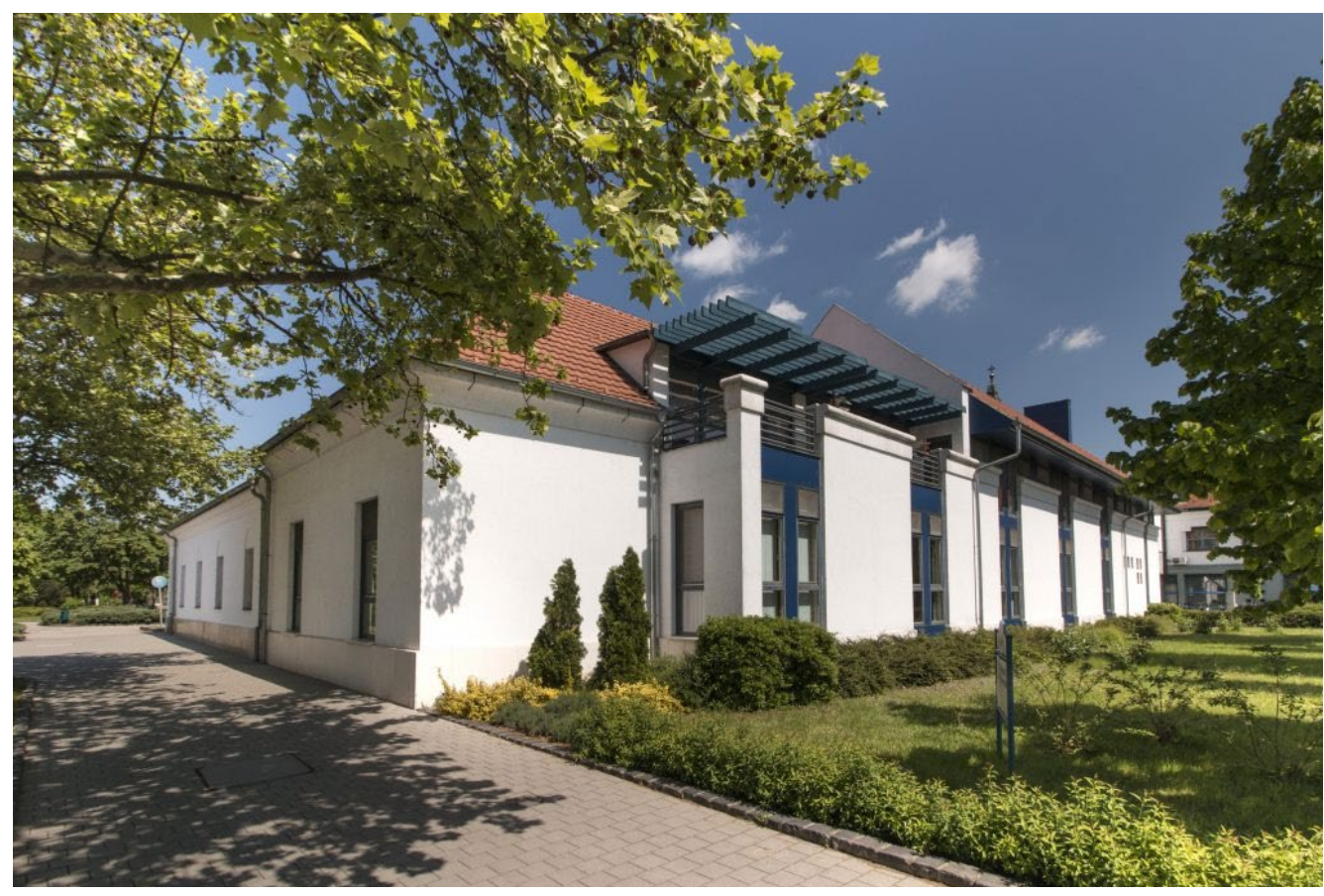

1. ábra: A kiskunfélegyházi Petöfi Sándor Városi Könyvtár új épületszárnya

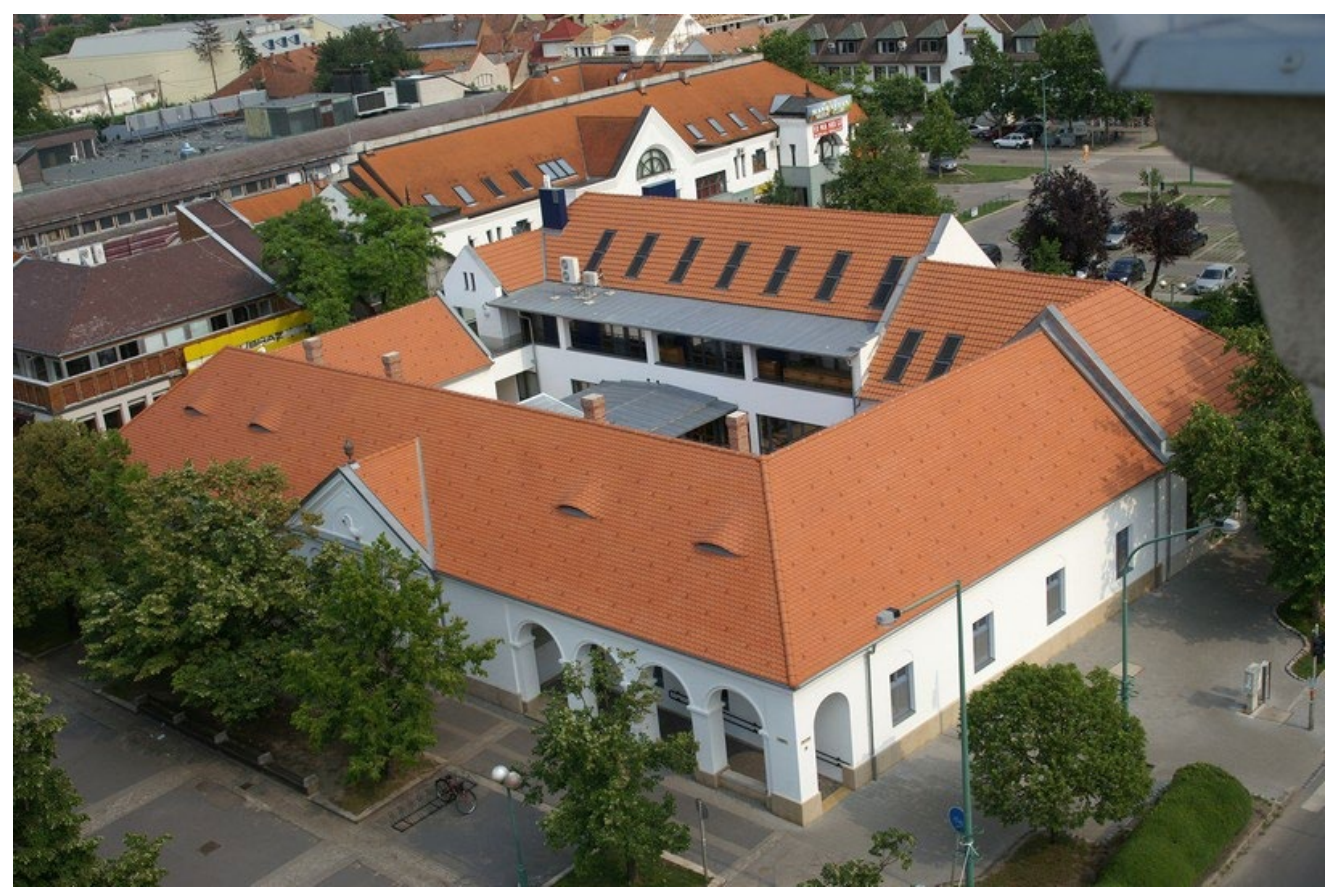

2. ábra: A városi könyvtár régi és felújitott épülete 


\section{A környezettudatos szemlélet kialakítása}

A környezettudatos szemlélet alakításának számos formájára szükség volt ahhoz, hogy könyvtárunkban is tudatosan alakítsuk környezetünket. Fontos a könyvtárosok hozzáállása, hivatástudata. Egy kisvárosban nem tömegközlekedéssel megyünk munkába, hanem gyalog vagy kerékpárral. Nagy gonddal terveztük az intézmény belső környezetét, szívesen fogadunk olvasóinktól virágokat, amelyekkel otthonosabbá tettük a részlegeket. Belső udvarunkat is virágosítottuk, raklapokból ülőhelyeket készíttettünk, az udvarunkba is kiülnek az olvasók olvasni. Nyári zenei rendezvényeinknek is kedvelt helyszíne a Hattyúkert.

Gyüjtjük a fenntartható fejlődéssel, a környezetvédelemmel, az értékkel kapcsolatos dokumentumokat, amelyekkel a helyi társadalom környezettudatos szemléletformásában veszünk részt.

Az ifuúság nevelése is kiváló lehetőség arra, hogy a legkisebb kortól a középiskolás korosztályig foglalkozásokon, kiállításokon keresztül az értékekre, a környezetvédelemre, a klímahelyzetre, a fenntarthatóságra irányítsuk a fiatalok figyelmét. A madarak és fák napja, a föld napja, a víz világnapja, az autómentes nap alkalmából tartott foglalkozások hozzájárulnak az ökoszemlélet formálásához városunkban.

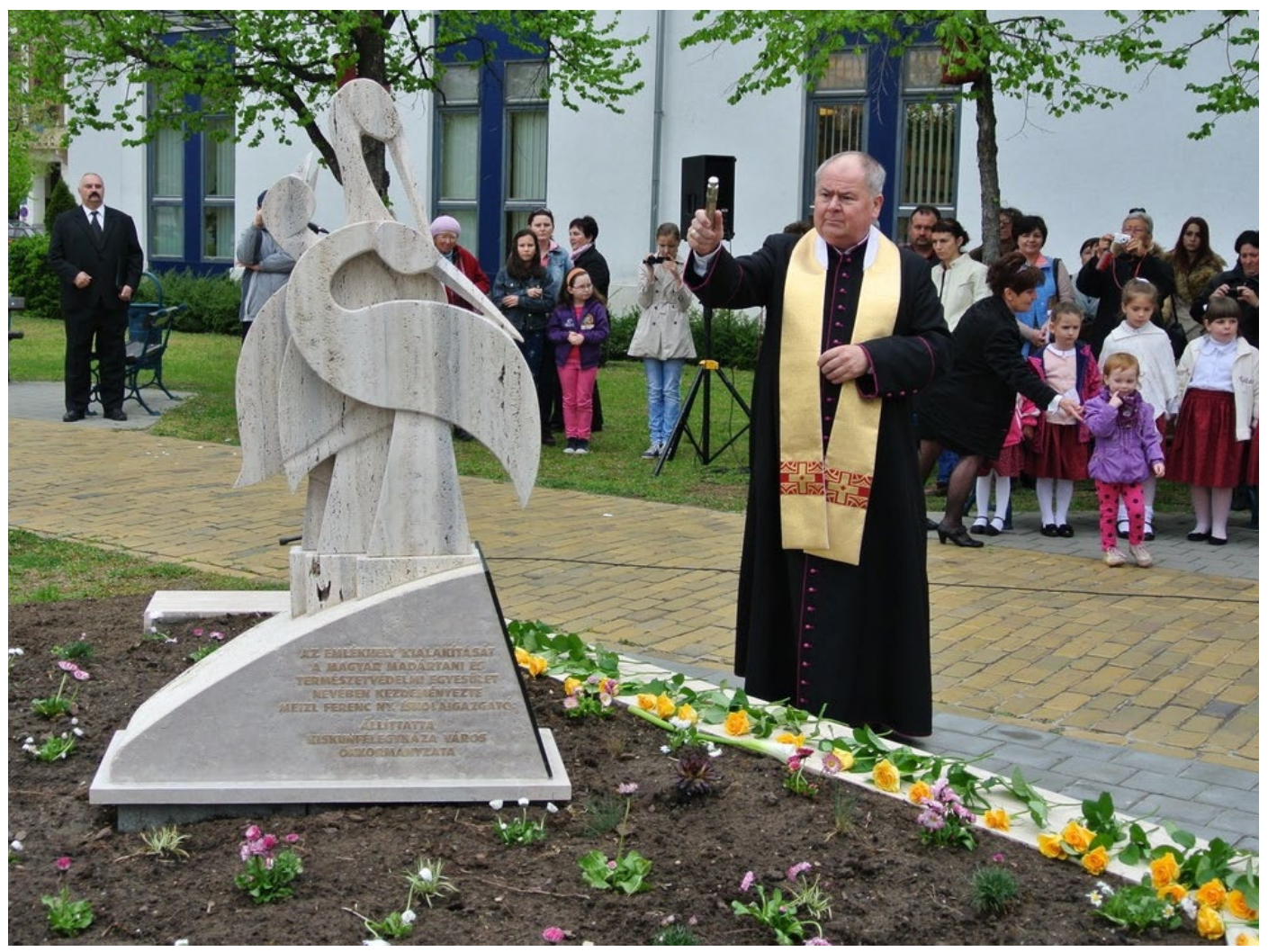

3. ábra: Herman Ottó emlékmü avatása a könyvtár mögötti parkban 


\section{1. Milyen környezetbarát elvek és gyakorlatok jellemzik könyvtárunk tevékenységét?}

A könyvtár épületének fenntartásában, az intézmény müködésében fontos szerepet kapnak a humánökológiai szempontok. Arra törekszünk, hogy a károsító hatások a müködés során minél alacsonyabb szinten legyenek jelen, amit többek között az energiatakarékossággal, az újrahasznosítással érhetünk el: ennek érdekében törekszünk energiatakarékos eszközök beszerzésére, ha lehet, megjavíttatjuk eszközeinket, nyomtatóinkba, fénymásolóinkba utántöltős patronokat szerzünk be, LED-es égőket vásárolunk, gyüjtjük a használt elemeket. Nyomtatás helyett digitális megoldásokra törekszünk (meghajtók, levelezőlista, mappák). Újrahasznosítjuk a könyvcsomagoló anyagokat, az egyoldalas papírt, törekszünk a helyiségekben a villanyok lekapcsolására.

Több éve műanyag kupakokat gyüjtünk egy, a városunkban élő, ma már felnőtté vált fiatalember számára, akinek szülei e bevételből gyógykészítményeket vásárolnak. Városunkban nyolc éve, ősztől kezdve a lakosságtól fogadjuk a megunt, kiolvasott gyermekkönyveket, -játékokat, -ruhákat, amelyeket decemberben ünnepélyes keretek között átadunk a Családok Átmeneti Otthona lakói számára.

\subsection{Közösségek a könyvtárban}

A könyvtáron belül müködő közösségek erősítik a közösségi szellemet és az összefogást. Ki kell emelnünk közülük a Madárbarát klubot, amely 2011 áprilisában alakult meg a városi könyvtárban, Meizl Ferenc nyugalmazott iskolaigazgató vezetésével. Tagjai vagyunk a Magyar Madártani Egyesületnek is, kezdeményeztük a Madárbarát könyvtár alprogram létrehozását. Madár- és természetszerető tagjaink évente 3-4 alkalommal találkoznak hasznos programok céljából a Gyermekbirodalomban.

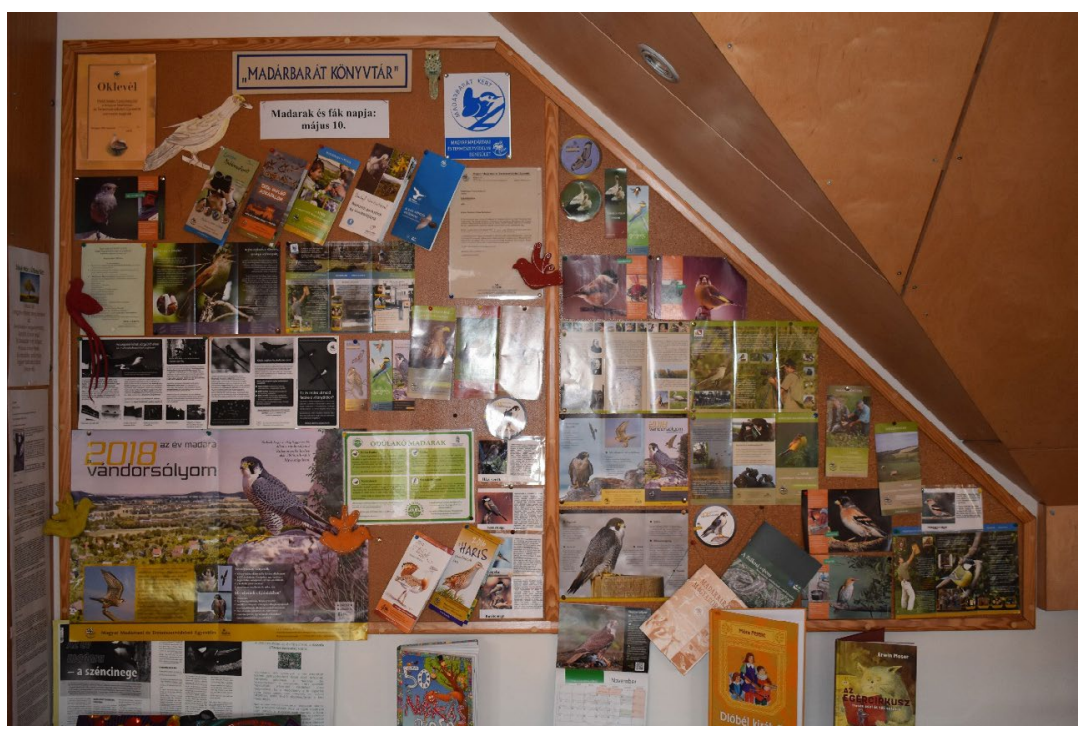

4. ábra: Madárbarát információs fal a Gyermekbirodalomban 


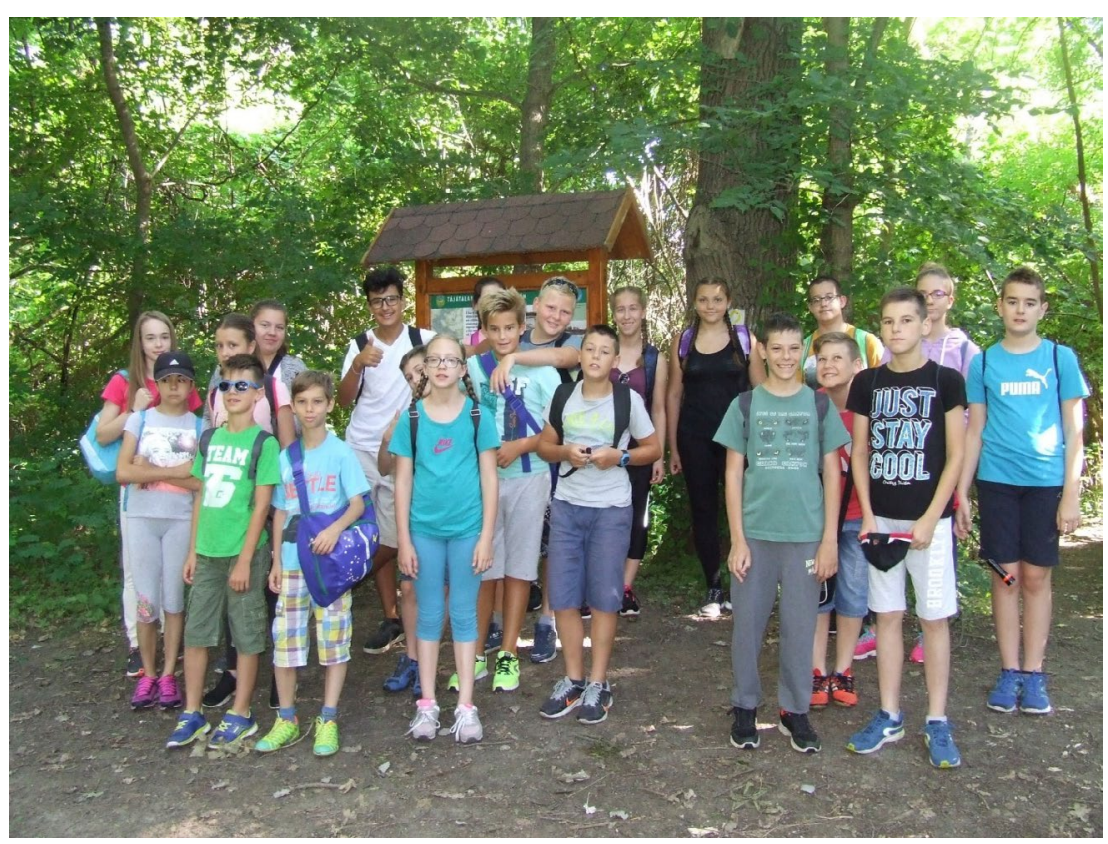

5 ábra: Az ökotábor résztvevői

A madárbarát csoportnak gyermek és felnőtt tagjai is vannak. A Gyermekbirodalomban parafa információs felületet alakítottunk ki, itt a klub hírei mellett híres ornitológusok, természetfotósok életrajza, a Magyar Madártani Egyesület cikkei, környezetünk madarai ismerhetők meg. A klub kirándulást szervezett a Péteri-tóhoz és Bugacra. Fontos szerepe van e látogatások alkalmával a madárhatározó könyveknek. Minden foglalkozáson ajánlunk könyveket, folyóiratokat. A klubvezető számos érdekes előadást tartott, meghirdettünk madarakról szóló fotókiállítást.

A könyvtár mögötti parkba madárkápolnák, a teraszra rovarhotel, madárodúk- és itatók készültek. Az erkélyről a gyerekekkel együtt rendszeresen etetjük és itatjuk a madarakat, így olvasóink is testközelből élvezhetik védenceink társaságát. A félegyházi könyvtár megkapta a Madárbarát könyvtári címet. (Ma már városunkban négy gyermekintézmény viseli e kitüntető címet). Egyre több szülő, intézményvezető ismeri fel, hogy a gyerekek ökoszemléletét formálni kell. Ugyanis a hagyományos tantárgyak mellett a jövőben szükség lesz erre az érzékenységre. A legkönnyebben a teljes kérdéskörről a madárvilág bemutatásával, ismertetésével lehet tájékoztatást adni.

A könyvtáron belül működő közösségek közül szólnunk kell a Betübölcsiről, az intézmény baba-mama klubjáról, amely 2008-ban alakult, kéthetente jönnek össze a kisgyermekes szülők. Bababarát címmel is rendelkezünk. Célja örömteli találkozások, ismeretterjesztő előadások tartása könyves környezetben. 2015-től a Nemzeti Egészségfejlesztési Intézet által auditált program. Foglalkozásai között több alkalommal szerepelt olyan téma, amely a környezettudatosságra hívta fel a figyelmet (mosható pelenkák, a hordozókendők használata, környezetbarát tisztítószerek alkalmazása, ruhadarabok újrahasznosítása). 


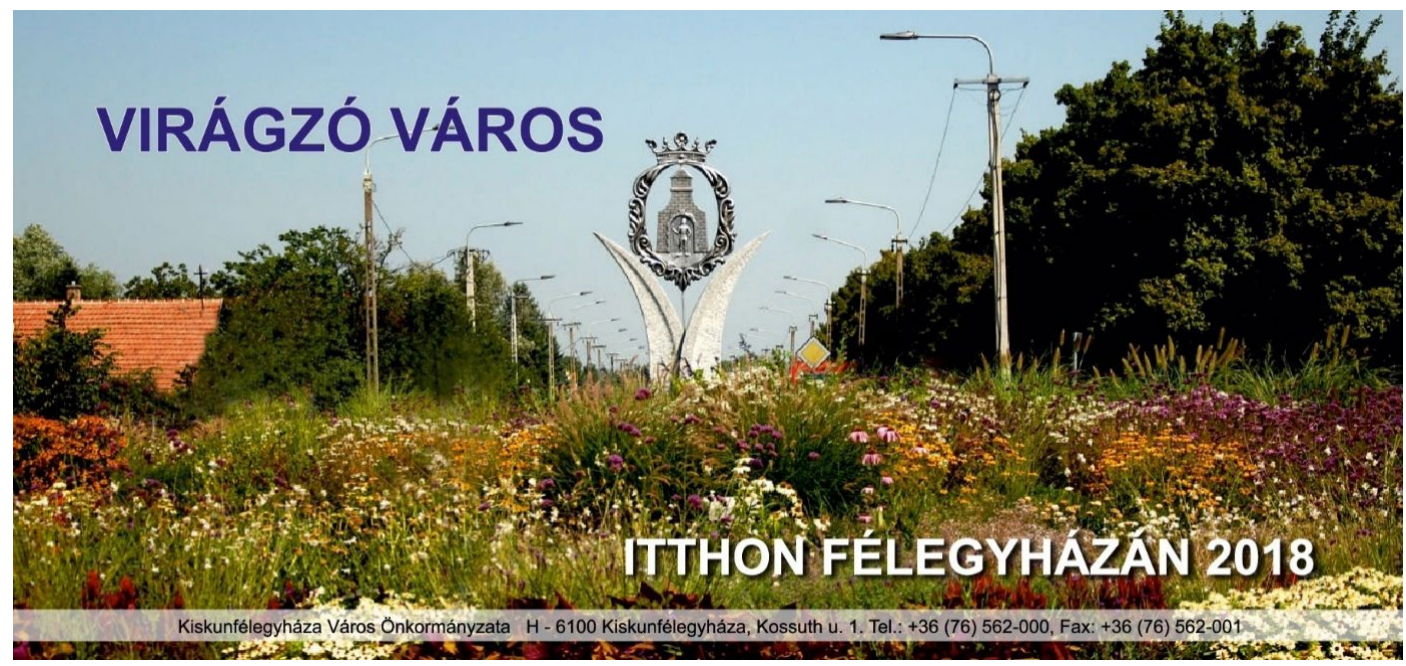

6. ábra: Virágzó város - Itthon Félegyházán címü városi naptár

Szinte minden könyvtár fontosnak tartja, hogy nyárra tábort szervezzen olvasói számára. A félegyházi könyvtárban a kisebbeknek olvasótábort, a nagyobbaknak helytörténeti tábort és 2017-ben, első alkalommal nyári öko-élménytábort szerveztünk az általános iskolák felső tagozatosainak. A gyerekek egy héten át tartalmas és intenzív programokon vehettek részt. A gyerekek sokat beszéltek a környezetvédelem, a fenntarthatóság és a klímaváltozás témaköreiről. Csoportokat alkotva mini projekteket készítettek, amelyeken rajzokkal ábrázolták, mit tartanak ők fontosnak a globális felmelegedéssel kapcsolatban. Bringabarát kerékpárboltba, majd a helyi szennyvíztisztító telepre látogattak, tőserdei túraösvényen vettek részt, ellátogattak egy biogazdaságba. A könyvtárban divatbemutatót tartottak, ahol saját készítésű ruhakölteményekben vonulhattak fel, amelyhez kartonokat és PET palackokat használtak fel.

A könyvtáron belül müködő civil kulturális szervezet - a Móra Ferenc Közművelődési Egyesület - nyolc éve kezdeményezte a virágos Félegyházáért mozgalmat, azzal a céllal, hogy a múlt értékeit megőrizzük, a jelen szépségeit ápoljuk, a jövő szép városát alakítsuk, virágosítsuk. E civil szervezet üléseinek, kezdeményezéseinek helyet ad a könyvtár, az egyesületi tagok mellett a könyvtár munkatársai is részt vesznek e programokban. A virágos verseny megbeszéléseit márciusban és áprilisban tartjuk, az április tavaszi virágünnepen tesszük közzé felhívásunkat, hogy minél többen szépítsék környezetüket.

Könyvtárunk is törekszik arra, hogy minél virágosabb legyen udvara, ebben partner az önkormányzat. A zsüri munkájába is bekapcsolódik intézményünk, dokumentáljuk a megtekintett kerteket. A virágos verseny értékelését, díjazását is a könyvtárban szervezzük meg és a Libafesztiválon történik meg a díjak átadása.

2017-ben megfogalmazódott az az igény, hogy az elkészült virágos fotókból állítsunk öszsze egy virágos naptárat. 2017 decemberére el is készült a Virágzó város - Itthon Félegyházán 2018 című asztali naptár, amely az évszakhoz igazodó fotókat és Petőfi, Móra idézeteket tartalmazott. Az egyedi, helyi naptár iránt nagy volt az érdeklődés, előjegyzésére a könyvtárban volt lehetőség. 


\section{Összegzés}

Munkánkban arra törekszünk, hogy a megújuló forrásokkal gazdaságosan, a nem megújuló energiaforrásokkal pedig takarékosan bánjunk. Cicero gondolataival valljuk: lehet..."

„Ha van egy kerted és egy könyvtárad, akkor mindened megvan, amire csak szükséged

\section{Irodalom}

BRÉM Zsuzsanna - DUBNICZKY Zsolt: Környezetbarát fenntarthatóság a könyvtárakban.

Forrás: https://docplayer.hu/69198992-Kornyezetbarat-fenntarthatosag-a-konyvtarakban.html [2018. március 1.]

DUBNICZKY Zsolt: Magok a könyvtárban. A mezőgazdaság, a könyvtár és a fenntarthatóság kapcsolatai. = Könyv, Könyvtár, Könyvtáros, 26. 3. 2017. 12-25. p.

GAZDAG Rita: Zöldkönyvtár a neten. = Könyvtári Levelező /lap, 14. 8. 2002. 23-24. p.

NAGYNÉ Simon Csilla: Környezettudatossági törekvések a könyvtárban. = Könyv, Könyvtár, Könyvtáros, 27. 1. 2018. 20-30. p.

NÁSZ János - NAGY Ádám: Az ökológiai gondolkodás erősítése Tatabánya város lakóközösségében könyvtári eszközökkel. Könyvtári Levelezö/lap, 25. 2. 2016. 13-18. p.

PEGÁN Anita: Fenntarthatóság és könyvtár. 1. rész.= Könyv, Könyvtár, Könyvtáros. 22. 6. 2013. 2634. p. Forrás: http://ki2.oszk.hu/3k/2013/06/fenntarthatosag-es-konyvtar-2/ [2018. február 27.]

PEGÁN Anita: Fenntarthatóság és könyvtár 2. rész. Zöld könyvtárak. = Könyv, Könyvtár, Könyvtáros, 22. 8. 2013. 9-15. p. Forrás: http://ki2.oszk.hu/3k/category/22-evfolyam/2013-8/ [2018. február 27.]

TURCSICS Annamária: A Pécsi Tudományegyetem Egyetemi Könyvtár és Tudásközpont Zöld Könyvtár projektje. = Orvosi Könyvtárak, 3. 2016. 24-25. p. Forrás: http://epa.oszk. hu/03100/03173/00031/pdf/EPA03173_orvosi_konyvtarak_2016_3.pdf\#page=24 [2018. február 27.]

Kállainé Vereb Mária a Kiskunfélegyházi Petőfi Sándor Városi Könyvtár igazgatója. Irányítása alatt a mủemlék Hattyúházhoz 2007-ben egy új épületszárny épült, így a könyvtár 2008-tól kétezer négyzetméteren szolgálja Kiskunfélegyháza és térsége lakosságát. Vezetése alatt az elmúlt tíz évben megújultak a könyvtár szolgáltatásai, számos új kezdeményezés kapcsolódik nevéhez (pl. az RFID bevezetése, könyvbedobó rendszer kialakítása). Tagja a Magyar Könyvtárosok Egyesületének, a Bács-Kiskun megyei szervezet ellenőrző bizottságának. Alapító tagja és ügyvezető elnöke a most 30 éves Kiskunfélegyházi Móra Ferenc Közművelődési Egyesületnek. Szerkesztésében közel 20 helytörténeti kiadvány látott napvilágot Kiskunfélegyházán. A „Kiskunfélegyházáért” kitüntető cím birtokosa. 